\title{
Sprawozdanie z Konferencji Naukowej „(R)ewolucja macierzyństwa”
}

W przeddzień Święta Matki - 25 maja 2015 roku w auli widowiskowej Wydziału Pedagogiki i Psychologii Uniwersytetu w Białymstoku odbyła się konferencja naukowa „(R)ewolucja macierzyństwa”. Organizatorami konferencji byli: Akademickie Koło Katolickiego Stowarzyszenia Młodzieży przy Uniwersytecie w Białymstoku, Katedra Historii Wychowania UwB, Katedra Teologii Katolickiej UwB oraz Katolickie Stowarzyszenie „Civitas Christiana”.

Celem konferencji była debata naukowa nad ważnym społecznie zagadnieniem, jakim jest macierzyństwo. Organizatorom szczególnie zależało na podkreśleniu ewolucji i rewolucji macierzyństwa jako przemiany w tożsamości płciowej kobiety, problemu odwlekania macierzyństwa w czasie, bądź całkowitego odłączenia macierzyństwa od współżycia seksualnego czy od małżeństwa. Zagadnienie macierzyństwa zostało także zanalizowane pod kątem wątków historycznych oraz etycznego wymiaru posiadania potomstwa i warunków, jakie temu towarzyszą.

Organizatorzy konferencji zadbali, aby temat macierzyństwa został omówiony z punktu widzenia różnych dyscyplin naukowych. Jako prelegenci wystąpili przedstawiciele różnych dziedzin naukowych: historii, pedagogiki, socjologii, prawa, medycyny i teologii. Spotkanie zostało otwarte przez dziekana Wydziału Pedagogiki i Psychologii UwB - prof. dra hab. Mirosława Sobeckiego, który nawiązał do sytuacji studentek, które w czasie studiów zostają matkami. Wystąpienia prelegentów były zróżnicowane, jednak zawierały troskę o los kobiety jako matki w kontekście historycznym, społecznym i kulturowym. 
Dr Małgorzata Jaszczuk-Surma swoje wystąpienie „Rewolucje społeczne a ewolucja rodziny?" rozpoczęła od przybliżenia znaczenia chrześcijaństwa w przemianach, jakie dotyczyły traktowania kobiety i jej potomstwa. Przekrojowo omówiła także epoki historyczne, uwzględniając dynamikę i jakość zmian społecznych dotyczących kobiety-matki. Kolejne wystąpienie „Wiara i zwątpienie matek - przestrzeń życiowa drugiej konspiracji” zaprezentowała prof. zw. dr hab. Elwira Kryńska. Wykorzystując swoje badania naukowe i liczne rozmowy z więźniarkami politycznymi i ich dziećmi, opisała macierzyństwo w bydgoskim

Sprawozdania i recenzje więzieniu - Fordonie. Wzruszające świadectwa i losy dzieci kobiet walczących w II konspiracji niepodległościowej pokazały słuchaczom smutne karty najnowszej historii Polski. Były także okazją prezentacji mało znanego tematu kobiet ,skazanych za patriotyzm”. Taki bowiem tytuł ma książka autorstwa Pani Profesor, w której można znaleźć więcej informacji na przedstawiony w referacie temat (E. J. Kryńska, Skazane za patriotyzm. Druga konspiracja na Białostocczyźnie 19451956, Białystok 2012).

Następnym prelegentem była prof. dr hab. Małgorzata Bieńkowska. Wykład „Społeczne wyobrażenie o macierzyństwie a rzeczywistość” był socjologicznym spojrzeniem na współczesne uwarunkowania posiadania potomstwa. Pani Profesor skupiła się na społecznym konstrukcie, czyli tym, jak społeczeństwo odnosi się do macierzyństwa. Wskazała tematy łatwe do debaty, jak też tematy traktowane stereotypowo oraz tabu związane z problemami macierzyństwa. Prawne aspekty posiadania dzieci przedstawiła dr Katarzyna Żywolewska. W referacie „Ochrona rodzicielstwa w prawie pracy” skupiła się na aktualnym prawodawstwie, które uznała za rewolucyjne. Wskazała szereg uprawnień nie tylko dla matek, ale także dla ojców, którzy spodziewają się powiększenia rodziny lub są w trakcie korzystania np. z urlopów według nowych przepisów. Niestety, pesymistycznym aspektem wystąpienia było zaznaczenie, że jedynie osoby mające umowę o pracę mogą korzystać z wielu uprawnień, których pozbawione są osoby bezrobotne czy pracownicy umów cywilno-prawnych. Medyczne aspekty macierzyństwa i konsekwencje wzrastającej liczby małżeństw borykających się z niepłodnością przedstawił dr Tadeusz Wasilewski. Wystąpienie Pana Doktora zawierało analizę problemów medycznych, z którymi zetknął się podczas swojej praktyki ginekologa/położnika. W wystąpieniu „Mój mały pacjent - tęsknota za macierzyństwem" nie zabrakło także wątków osobistych. Pan Doktor podkreślał dylematy etyczne, jakie dzisiaj dotykają lekarzy ginekologów. Zaprezentował także swój zespół ekspertów, z pomocą których osiąga 
sukcesy w postaci szczęśliwych poczęć i narodzin dzieci u małżeństw, które wiele lat czekały na potomstwo.

Część wykładową zakończył biblista - ks. dr Zbigniew Skuza. Zawierający wiele odniesień do antropologii człowieka wykład „Kobieta - żona i matka, niezastąpiona i ciągle na nowo odkrywana” był nawiązaniem do dzisiejszej sytuacji kobiety. Ksiądz Skuza podzielił się także swoimi doświadczeniami ze studiów w Jerozolimie oraz Rzymie, gdzie kobieta przeżywa macierzyństwo w różnych kontekstach kulturowych.

Po zakończonych wykładach prelegentów zaproszono do naukowej dyskusji. O przyjazną atmosferę podczas debaty zadbał konferansjer - Sprawozdania Pan Krzysztof Szubzda, który prowadził całą konferencję. Większość pytań z sali była skierowana do dr. Tadeusza Wasilewskiego, ale były także pytania poruszające kwestie prawne i socjologiczne. Każdy z uczestników debaty miał szanse na podsumowanie konferencji i odniesienie się do wystąpień pozostałych prelegentów. Czterogodzinne spotkanie naukowe spotkało się z życzliwym odbiorem studentów i kadry naukowej UwB oraz przybyłych gości. W konferencji wzięło udział ponad 300 uczestników, co motywuje organizatorów do dalszej pracy nad (r)ewolucyjnymi zagadnieniami życia społecznego.

Galerię zdjęć z konferencji, materiał filmowy i więcej informacji można znaleźć na stronie internetowej: www.rewolucjamacierzynstwa.pl. 